УДК 656.078.8:656.2

\title{
ФОРМУВАННЯ КОНКУРЕНТНОГО СЕРЕДОВИЩА ЯК ФАКТОР ЗАБЕЗПЕЧЕННЯ СТАЛОГО РОЗВИТКУ ЗАЛІЗНИЧНОГО ТРАНСПОРТУ
}

\author{
Каличева Н.С., к.е.н., доцент, \\ Політасв Д.Б., студент, \\ торопова Д.Д., магістр (УкрДУЗТ)
}

У статті розкрито особливості формування конкурентного середовища для залізничного транспорту в умовах сучасного ринку. Зауважено, щчо формування конкурентного середовища є досить тривалим прочесом. Визначена нова система поглядів на управління залізничним транспортом шляхом впровадження ринкових перетворень у вітчизняній транспортній системі. Обтрунтована необхідність та можливість забезпечення конкурентоспроможності суб'єктів вітчизняного залізничного комплексу на ринку транспортних послуг.

Ключові слова: залізничний транспорт, конкуренція, конкурентоспроможність, ринок транспортних послуг, перевізний процес, розвиток, ринкова економіка.

\section{ФОРМИРОВАНИЕ КОНКУРЕНТНОЙ СРЕДЫ КАК ФАКТОР ОБЕСПЕЧЕНИЯ УСТОЙЧИВОГО РАЗВИТИЯ ЖЕЛЕЗНОДОРОЖНОГО ТРАНСПОРТА}

Каличева Н.Е., к.э.н, доцент, Политаев Д.Б., студент, торопова Д.Д., магистр (УкрГУЖТ)

В статье раскрыты особенности формирования конкурентной среды для железнодорожного транспорта в условиях современного рынка. Замечено, что формирование конкурентной среды является достаточно длительным прочессом. Определена новая система взглядов на управление железнодорожным транспортом путем внедрения рыночных преобразований в отечественной транспортной системе. Обоснована необходимость и возможность обеспечения конкурентоспособности субъектов отечественного железнодорожного комплекса на рынке транспортных услуг.

Ключевые слова: железнодорожный транспорт, конкуренция, конкурентоспособность, рынок транспортных услуд, перевозочный процесс, развитие, рыночная экономика.

(C) Каличева Н.Є.,

Політаєв Д.Б.,

Торопова Д.Д.

Вісник економіки транспорту і промисловості № 66, 2019 


\title{
FORMATION OF COMPETITIVE ENVIRONMENT AS A FACTOR FOR ENSURING SUSTAINABLE DEVELOPMENT OF RAILWAY TRANSPORT
}

\author{
Kalicheva N.E., candidate of economic sciences, associate professor, \\ Politaiev D.B., studen, \\ Toropova D.D., master's degree (UkrSURT)
}

Efficient operation of rail transport in modern conditions has a direct dependence on the conditions of market activity. Therefore, the necessary direction of policy in the field of rail transport development, as outlined in relevant programs and concepts, is the focus on the creation of a market with competition between carriers under the conditions of regulating access to infrastructure. Such an approach will contribute to the formation of an effective competitive environment in the transport services market and will encourage the industry to improve its performance. Indeed, the presence of competition in the market encourages enterprises to work more efficiently by expanding market offers, which for transport companies involves the introduction of new forms of service and services in the implementation of transportation work.

The activity of transport companies is a complex technological process, because the results of their work are displacement, that is, the beneficial effect is determined by the delivery of goods or customers to the final destination. Under such conditions, the transport service becomes a special commodity and is defined as a means of transfer, which one party (carrier) can provide to another (client).

It should be noted that the transport services market is quite monopolistic, even oligopoly, which is due to the presence of a significant number of sellers and buyers and the lack of an effective mechanism for monitoring the cost of the transport process. There is also a specialization in providing the same services. For example, when traveling at small distances, the customer of transport services almost always prefers road transport over the railroad. But the efficiency of such a market is insignificant, as the inseparable component of a modern market economy is the formation and development of a competitive environment as a factor that has a direct impact on the competitor's interaction of all market participants.

Ensuring the efficient development of rail transport in today's marketplace has a significant dependence on the formation and development of an effective competitive environment. This is due to the ability of railways to carry out transportation work at market value, which will direct the accumulation of funds for upgrading and further development of the industry, and allows customers to develop their own railway departments in accordance with their needs.

Keywords: railway transport, competition, competitiveness, transport services market, transportation process, development, market economy.

Постановка проблеми та її зв'язки $з$ науковими чи практичними завданнями. Ефективне функціонування залізничного транспорту в сучасних умовах має пряму залежність від умов діяльності на ринку. Тому необхідним напрямком політики в сфері розвитку залізничного транспорту, що окреслено у відповідних програмах та концепціях, $\epsilon$ орієнтація на створення ринку 3 конкуренцією між перевізниками на умовах регулювання доступу до інфраструктури. Такий підхід сприятиме формуванню дієвого конкурентного середовища на ринку транспортних послуг та спонукатиме галузь до покращення показників діяльності. Адже наявність конкуренції на ринку спонукає

Вісник економіки транспорту і промисловості № 66, 2019 
підприємства працювати більш ефективно за рахунок розширення ринкових пропозицій, що для підприємств транспорту заключається у запровадженні нових форм сервісу та послуг при реалізації перевізної роботи.

Аналіз останніх досліджень i публікацій. Питанням конкурентного розвитку залізничного транспорту присвячено значну кількість наукових праць, зокрема варто виділити роботи Головкової Л.С., Диканя В.Л., Ейтутіса Г.Д., Мукмінової Т.А., Цвєтова Ю.М. та ін. [1-5]. Та постійна динамічність ринкової економіки та потреба впровадження конкурентних механізмів у діяльність вітчизняного залізничного транспорту потребують перегляду та корегування підходів до формування дієвого конкурентного середовища для залізничного транспорту. тим більше, що, незважаючи на розроблені та запроваджені програми та концепції розвитку, реальних змін у діяльності галузі в наслідок реформування не відбувається.

Мета статті. Дослідження питань формування конкурентного середовища для вітчизняного залізничного транспорту в сучасних умовах для забезпечення їх стабільного та ефективного функціонування на ринку.

Викладення основного матеріалу дослідження. Діяльність підприємств транспорту $\epsilon$ складним технологічним процесом, адже результатам їхньої роботи $\epsilon$ переміщення, тобто корисний ефект визначається через доставку товарів чи клієнтів в кінцевий пункт призначення. За таких умов транспортна послуга стає особливим товаром та визначається як спосіб 3 переміщення, котрий одна сторона (перевізник) може надати іншій (клієнту).

Участь у реалізації перевізного процесу приймають виробники, споживачі, замовники, транспортні підприємства, посередники та ін. Наявність значної кількості учасників перевізного процесу зумовлена специфікою функціонування транспортного ринку, адже замовник транспортних послуг може бути їхнім споживачем, наприклад експедитор, а продавець транспортних послуг може не бути їхнім безпосереднім виробником. Це зумовлено тим, що сучасний ринок транспортних послуг характеризується значною кількістю посередницьких організацій, які відповідають за перевізний процес, але не $\epsilon$ самим перевізником. Така особливість транспортного ринку необхідна для більш широкого задоволення потреб клієнтів при реалізації транспортної роботи за рахунок надання широкого спектру супутніх та логістичних послуг, але відсутність прямого контакту безпосередньо перевізника із споживачем призводить до втрати останніми прямого зв'язку з ними, що може негативно впливати на якість перевізного процесу [6].

Потрібно зазначити, що ринок транспортних послуг $є$ досить монополістичним, навіть олігапольним, що виражається через наявність значної кількості продавців та покупців і відсутністю дієвого механізму контролю за вартістю перевізного процесу [7]. Також присутня спеціалізація при наданні одних і тих самих послуг. Наприклад, при перевезеннях на малі відстані замовник транспортних послуг практично завжди віддає перевагу автомобільному транспорту над залізничним. Але ефективність такого ринку є незначною, адже невіддільною складовою сучасної ринкової економіки є становлення та розвиток відповідного конкурентного середовища, як фактору, що має безпосередній вплив на конкуренту взаємодію всіх учасників ринку (рис. 1). 


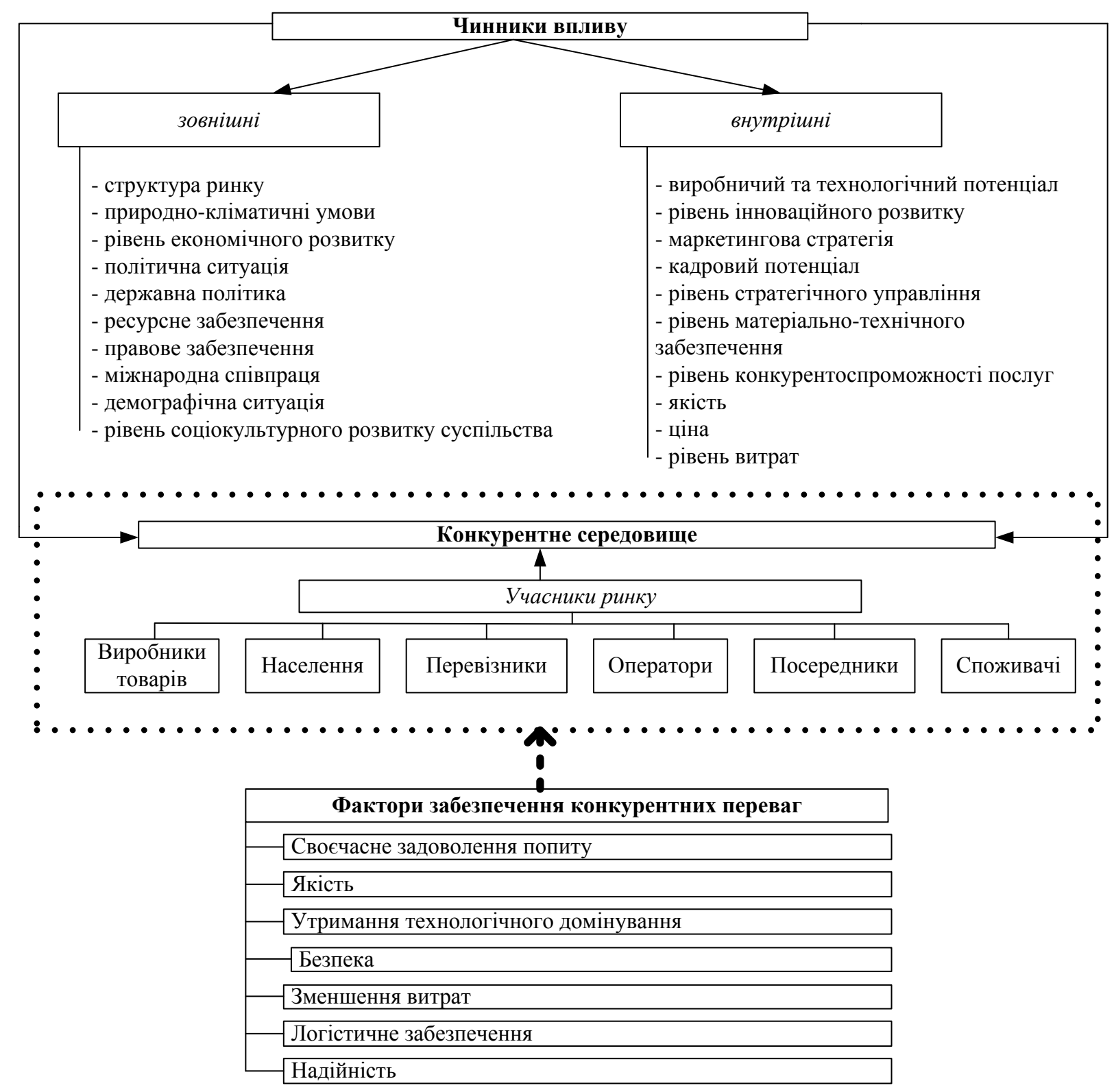

Рис. 1. Індикатори формування конкурентного середовища для залізничного транспорту на ринку транспортних послуг

Для залізничного транспорту наявність дієвого конкурентного середовища $\epsilon$ стимулюючим чинником щодо підвищення ефективності роботи на ринку транспортних послуг. Адже в сучасних умовах залізниці поступово втрачають свої конкуренті позиції на ринку. Це пов'язано в першу чергу із зниженням об'ємів виробництва та, відповідно, скороченням перевізної роботи, збільшенням обсягів перевезень автомобільним транспортом, скороченням транзитних перевезень та інших факторів, що зумовлено скороченням рівня технікотехнологічного оновлення Ta інноваційного розвитку залізничної галузі i, відповідно, зниженням рівня якості перевізного процесу [8].

Реформаційні процеси, які протягом останніх років вібуваються на вітчизняному залізничному транспорті, спрямовані на покращення позицій галузі на транспортному ринку. Але, як уже було зазначено вище, більшість заходів, які було здійснено в процесі реформування, не дали дієвого результату щодо

Вісник економіки транспорту і промисловості № 66, 2019 
підвищення ефективності її роботи.

Попри все залізничний транспорт має завойовувати свої позиції на ринку транспортних послуг за рахунок відповідності міжнародним вимогам за швидкістю, надійністю, безпекою, інтермодальністю та іншими факторами, використовуючи наявні потенційні можливості, що сприятимуть утриманню наявних конкурентних переваг та завоюванню нових [9].

За таких умов держава має проводити дієву транспортну політику для підтримки залізничного транспорту на ринку транспортних послуг шляхом нормативно-правової підтримки, створення умов для формування конкурентного середовища, підвищення рівня конкурентоспроможності залізничних перевезень за рахунок зростання рівня науково-технічного забезпечення, підвищення конкурентоспроможності національного виробництва через орієнтацію та інноваційну модель розвитку [10].

Таким чином на даний час в умовах реформування для створення дієвого конкурентного середовища для залізничного транспорту необхідно звернути увагу на такі чинники, як тариф, персоналізація послуг та технологічна стійкість і безпека перевізного процесу.

Розглядаючи ці чинники більш детально, необхідно зазначити, що для отримання прибутку залізничним транспортом на рівні необхідному для погашення інвестицій для окупності запозичених засобів за час їхнього життєвого циклу потрібно відмовлятися від субсидування нерентабельних перевезень та формувати тарифи із врахуванням рівня вартості товару, що перевозиться. А так як більшість пасажирських перевезень в нашій країні $є$ соціальними, то має бути розроблений дієвий механізм компенсації за такі перевезення із місцевих та центрального бюджетів. Також при нарахуванні тарифу має враховуватися плата за доступ до інфраструктури та вартість послуг за перевезення.

Важливе значення має й персоніфікація послуг, що виражається в стимулюванні основних груп споживачів транспортних послуг до придбання власного чи взяття в оренду наявного рухомого складу та вкладання коштів у оновлення та розвиток залізничної інфраструктури для збільшення пропускної спроможності залізничних станцій та вантажних потужностей.

Також залізничний транспорт пропонує додаткові послуги, зокрема надання колій для простою рухомого складу, доступ до інформаційних та телекомунікаційних мереж, постачання паливо-мастильних матеріалів та ін.

A дотримання безпеки на коліях загального та незагального користування має здійснювати держава шляхом встановлення відповідних норм та стандартів та контролем за їхнім дотриманням.

Висновки.

Забезпечення ефективного розвитку залізничного транспорту в умовах сучасного ринку має значну залежність від становлення та розвитку дієвого конкурентного середовища. Це виражається через можливість залізниць здійснювати перевізну роботу за ринковою вартістю, що спрямите накопиченню коштів на оновлення та подальший розвиток галузі, та дозволяє клієнтам розвивати власні залізничні підрозділи відповідно до наявних потреб.

\section{ПЕРЕЛІК ВИКОРИСТАНИХ ДЖЕРЕЛ}

1. Головкова Л. С., Омельчак Г. В. Забезпечення конкурентоспроможності залізничного транспорту України в умовах євроінтеграції. Проблеми економіки транспорту: збірник наукових праць ДНУЗТ ім. ак. В. Лазаряна. 2014. Вип. 7. С. $80-87$

2. Дикань В. Л., Корінь М. В. Ефективність роботи транспортної системи України в умовах глобалізації економічних систем. Вісник економіки

Вісник економіки транспорту і промисловості № 66, 2019 
транспорту і промисловості: збірник науково-практичних статей. Харків: УкрДАЗТ, 2011. № 33. С. 13-19.

3. Ейтутіс Г. Д. Теоретикопрактичні основи реформування залізниць України: монографія. Ніжин: ТОВ «Видавництво «Аспект-Поліграф», 2009. 240 c.

4. Мукмінова Т. А. Ринкова трансформація суб'єктів господарювання на залізничному транспорті. Економікоматематичне моделювання соціальноекономічних систем. 2007. № 12. С. 2937.

5. Трансформація економіки та транспорт України / Цвєтов Ю.М., Макаренко М.В., Цвєтов М.Ю., Левченко О.В. та ін. К.: ДЕТУТ, 2012. 180 с.

6. Каличева Н. Є., Маслова В. О. Логістичні підходи, як основа раціональної організації виробничого процесу на підприємстві. Вісник економіки транспорту i промисловості: збірник науково-практичних статей. Харків: УкрДАЗТ, 2014. № 47. С. 83 - 86.

7.

конкурентоспроможності підприємств: підручник / В. Л. Дикань та ін. Харків: УкрДАЗТ, 2012. 415 с.

8. Каличева Н. Є. Методологічні аспекти

конкурентоспроможності

підвищення підприємств залізничного транспорту за рахунок управління конкурентними позиціями. Науковий вісник Херсонського державного університету. Сер.: Економічні науки. Херсон, 2017. Вип. 27. Ч. 1. -C. $139-142$.

9. Токмакова I. В. Забезпечення гармонійного розвитку залізничного транспорту України: монографія. Харків: УкрДУЗТ, 2015. 403 с.

10. Каличева Н. Є. Підходи до управління конкурентними перевагами підприємств залізничного транспорту. Причорноморські економічні студії: науковий журнал. Одеса, Причорноморський науково-дослідний інститут економіки та інновацій, 2017. Вип. 21. С. 86-91.

\section{REFERENCES}

(2014)

konkurentospromozhnosti

transportu Ukrajiny

jevrointeghraciji. the context of European integration]. Problems of transport economy: a collection of scientific works DNUZT them. ac $V$. Lazaryan. Vol. 7. pp. 80-87

2. Dykanj V. L., Korinj M. V. (2011) Efektyvnistj roboty transportnoji systemy Ukrajiny $\mathrm{v}$ umovakh ghlobalizaciji ekonomichnykh system. [Efficiency of the transport system of Ukraine in the conditions of globalization of economic systems] The bulletin of Transport and Industry Economics. No 33, pp. 13-19.

3. Ejtutis Gh. D. (2009) Teoretykopraktychni osnovy reformuvannja zaliznycj Ukrajiny: monoghrafija. [Theoretical and practical basics of reforming the railways of Ukraine: monograph.] Nizhyn: TOV «Vydavnyctvo «Aspekt-Polighraf» (in Ukrainian)

4 Mukminova T. A. (2007) Rynkova transformacija sub'jektiv ghospodarjuvannja na zaliznychnomu transporti. [Market transformation of subjects of management on the railway transport]. Economicmathematical modeling of socio-economic systems. No 12. pp. 29-37.

5. Transformacija ekonomiky ta transport Ukrajiny / Cvjetov Ju.M., Makarenko M.V., Cvjetov M.Ju., Levchenko O.V. ta in. K.: DETUT, 2012. $180 \mathrm{~s}$.

6. Kalicheva N.E., Maslova V.A. (2014) Loghistychni pidkhody, jak osnova racionaljnoji orghanizaciji vyrobnychogho procesu na pidpryjemstvi [Logistic approaches as the basis of rational organization of the production process at the enterprise]. The bulletin of Transport and Industry Economics. No 47, pp. 83-86.

7. Dy`kan` V. L., Borovy`k Yu. T., Polyakova O. M., Utkina Yu. M. (2011) Zabezpechennya konkurentospromozhnosti

Вісник економіки транспорту і промисловості № 66, 2019 
pidpry yemstv [Ensuring the competitiveness of enterprises]. UkrDAZT. (in Ukrainian)
8.
Kalicheva
N.E.
(2017)

Metodologhichni aspekty pidvyshhennja konkurentospromozhnosti pidpryjemstv zaliznychnogho transportu za rakhunok upravlinnja konkurentnymy pozycijamy [Methodological aspects of increasing the competitiveness of railway companies through the management of competitive positions]. Scientific Herald of Kherson State University. Series: Economic Sciences. Vol. 27. No 1, pp. 139 - 142

9. Tokmakova I.V. (2015) Zabezpechennja gharmonijnogho rozvytku zaliznychnogho transportu

Ukrajiny: monoghrafija [Ensuring the harmonious development of rail transport in Ukraine: a monograph]. Kharkiv: Ukrainian State University of Railway Transport. (in Ukrainian)

10. Kalicheva N.E. (2017) Pidkhody do upravlinnja konkurentnymy perevaghamy pidpryjemstv zaliznychnogho transportu [Approaches to managing the competitive advantages of rail transport enterprises]. Black Sea Economic Studies: Scientific Journal. Vol 21, pp. 86-91

\title{
ФОРМУВАННЯ СИСТЕМИ КАДРОВОГО ЗАБЕЗПЕЧЕННЯ РОЗВИТКУ ІНФРАСТРУКТУРИ ЗАЛІЗНИЧНОГО ТРАНСПОРТУ В ТРАНСКОРДОННИХ РЕГІОНАХ
}

\author{
Корінь М.В., к.е.н, доцент, \\ Кондратюк М.В., к.е.н., доцент, \\ Фарафонова О.В., магістр (УкрДУЗТ)
}

В статті визначено зовнішні фактори, щзо впливають на управління кадровим потенціалом залізничного транспорту та проєктів розбудови його інфраструктури на транскордонних територіях. Розкрито особливості формування системи кадрового забезпечення розвитку інфраструктури залізничного транспорту в транскордонних регіонах, яка визначає комплекс технологій та інструментарію 3 підтримки ефективної роботи команди, вирівнювання ринку прачі транскордонного регіону та створення дієвої системи професійного навчання. Внесено пропозиџї щзодо здійснення мотивації персоналу команди проєкту розвитку інфраструктури відповідно до рівня компетентності та присвоєного статусу працівника.

Ключові слова: кадровий потенціал, система кадрового забезпечення, інфраструктурний проект, залізничний транспорт, компетенцї̈, статус працівника.

(C) Корінь М.В., Кондратюк М.В., Фарафонова О.В. 